\title{
A single nucleotide polymorphism in Wilms' tumor 1 gene and the risk of acute myeloid leukemia in Sudan
}

\author{
Amr A. Ahmed ${ }^{1 *}$, H B. Eltahir ${ }^{2}$, Malik HI Mustafa ${ }^{3}$, Munsoor M. Munsoor ${ }^{4}$ \\ From 2nd International Genomic Medical Conference (IGMC 2013) \\ Jeddah, Kingdom of Saudi Arabia. 24-27 November 2013
}

\section{Background}

The diagnosis, prognosis, and treatment of acute myeloid leukemia (AML) have been transformed to be based on genetic, genomic, and molecular characteristics of the disease. Wilms' tumour (WT1) is an important regulatory molecule involved in cell growth and development [1-3]. WT1 is highly expressed in the bone marrow or peripheral blood of a variety of leukemia.

\section{Materials and methods}

This study was designed to investigate the involvement of WT1 gene mutation in the development of Acute Myeloid Leukemia in Sudan. The study involved 51 patients and 75 healthy controls. Genomic DNA was isolated from peripheral blood leukocytes using salting out method. PCR amplification of the target sequence (214 bp) within exon7 of WT1 gene was carried out. The known A $\rightarrow$ G transition mutation that destroys an AflIII restriction enzyme recognition site was detected by RFLP analysis.

\section{Results}

The study revealed that $43.14 \%$ of cases (22/51 patients) were heterozygous A/G and only $3.92 \%(2 / 51)$ were homozygous $\mathrm{G} / \mathrm{G}$ for the mutant allele on the other hand $26.67 \%$ (20/75 controls) were heterozygous A/G and the homozygous $\mathrm{G} / \mathrm{G}$ genotype was not observed in any of the controls. The study showed a significant difference in the frequency of the mutant WT1 allele between patients $25.49 \%$ and controls $13.33 \%$.

\section{Conclusions}

In the Sudanese population, the Wilms' tumour (WT1) gene $A \rightarrow G$ mutation appears to be associated with increased risk of developing Acute Myeloid Leukemia. The disease was found to be associated with the heterozygous genotype.

\section{Authors' details \\ 'Alnomais Medical \& Pharmacies Group, Abha, Saudi Arabia. ${ }^{2}$ Department of Biochemistry, Faculty of Medicine, University of El Imam El Mahdi, Sudan. \\ ${ }^{3}$ Department of Medical Lab Sciences, College of Applied Medical Science, Taif University, Saudi Arabia. ${ }^{4}$ Department of Heamatology, Faculty of Medical Laboratory Science, Sudan University of Science and Technology, Sudan.}

Published: 2 April 2014

\section{References}

1. King-Underwood L, Renshaw J, Pritchard-Jones K: Mutations in the Wilms' tumor gene WT1 in leukemias. Blood 1996, 2171-2179.

2. King-Underwood L, Little S, Baker M, Clutterbuck R, Delassus S, Enver T, et al: Wt1 is not essential for hematopoiesis in the mouse. Leuk Res 2005, 29:803-812.

3. Ellisen LW, Carlesso N, Cheng T, Scadden DT, Haber DA: The Wilms tumor suppressor WT1 directs stagespecific quiescence and differentiation of human hematopoietic progenitor cells. EMBO J 2001, 20:1897-1909.

doi:10.1186/1471-2164-15-S2-P43

Cite this article as: Ahmed et al:: A single nucleotide polymorphism in Wilms' tumor 1 gene and the risk of acute myeloid leukemia in Sudan. BMC Genomics 2014 15(Suppl 2):P43.

\footnotetext{
* Correspondence: amri_aljallad@hotmail.com

${ }^{1}$ Alnomais Medical \& Pharmacies Group, Abha, Saudi Arabia

Full list of author information is available at the end of the article
}

(c) 2014 Ahmed et al; licensee BioMed Central Ltd. This is an Open Access article distributed under the terms of the Creative Commons 